\title{
The Increase in the Efficiency of Coal Sludge Thickening Due to Changes in the Process of Flocculant Selection
}

\author{
Dmitrii Frolov ${ }^{1}$, Vladimir Udovitsky ${ }^{1, *}$, and Vadim Frolov ${ }^{2}$ \\ ${ }^{1}$ T.F. Gorbachev Kuzbass State Technical University, Department of Mineral Processing, 650000 \\ Kemerovo, 28 Vesennya st., Russian Federation \\ ${ }^{2}$ BASF, 31582 Nienburg/Weser, 97 Große Drakenburger Str., Germany
}

\begin{abstract}
Coal preparation currently has a number of significant problems concerning the dewatering processes (water purification, coal sludge thickening). These processes polymeric flocculants are used to their enhancement. To select a floculant for its further use at the preparation plant is currently a quite complicated and mainly empirical process. The authors have conducted research in order to establish a possibility to recommend certain flocculants to be chosen based on the properties of coal pulp, that were established during the experiments, and the properties of the aforementioned flocculants. In this paper are listed the methods, that were used during the research, the results of the laboratory tests of anionic flocculants Magnaflock, that were conducted on various coal pulp samples with various properties. The industrial testing of the selected flocculant at the coal preparation plant "Anzherskaya" was examined in detail. After the analysis of the obtained results certain conclusion was conducted.
\end{abstract}

\section{Introduction. Methods of the research}

Nowadays the coal preparation processes are widely used in order to lower the mined coal transportation costs, to increase the quality of coal and reduce its prime cost. Coal preparation became de facto a mandatory step in the thecknological process of high-energy fuel production. During that, to enchance certain supporting processes (water purification, coal sludge thickening), modern high-molecular technical materials are used, that are called flocculants. They can, at a relatively low specific consumption, abruptly increase the speed of the process and the solid-liquid phases separation efficiency. It allows to significantly improve the economic efficiency of the whole production process [1].

There exist many factors that can influence the flocculation process. They can be connected to the properties of the dewatered suspension (density, specific surface, zetta potential, material composition, degree of hydration, salt composition, $\mathrm{pH}$ value, temperature, electrical conductivity, rigidity) [2-6], or to the properties of the flocculant in use (ionogenicity, molecular weight, solution concentration, $\mathrm{pH}$ value) [7-12].

\footnotetext{
* Corresponding author: $\underline{\text { uvi@ } @ \text { kuzstu.ru }}$
} 
Because of this, each coal preparation plant needs the selective flocculant selection, to optimize the coal sludge thickening processes. It must be noted that even the slightest change in the properties of the processed coal can lead to a significant downgrade in the flocculation process. This will thus lead to the inability to follow the established optimal parameters of the process, and the reduction in its efficiency [13-15].

The main purpose of our research was the selection of a flocculant to use at the preparation plant due to the processed coal pulp analysis and the further correlation of its properties with the properties of the selected flocculant.

Establishing the influence of of physico-chemical characteristics of the disperse system on the efficiency of the coal sludge flocculation will allow to reduce the possibility of the formentioned problems occurrence and to recommend a specific flocculant to use under those conditions without directly testing it on the processed coal pulp. In order to achieve this, four series of lab test were conducted on various coal sludge samples from the coal preparation plant "Anzherskaya". After that, the industrial testing was conducted directly at the plant.

Coal preparation plant "Anzherskaya" was chosen due to a large range of processed coal: the plant processes coal from various mining facilities in Kuzbass region. Among them there are coals of various brands. It comes as surprise that a dispersion like this leads to significant fluctuations in the solid material properties during the thickening in the radial thickeners. Besides, at the plant for a long time exists a number of problems concerning the flotation tails thickening. It is caused not only by the fluctuations of the coal properties, but also by some particularities in the process of coal flocculation.

While conducting laboratory tests, the following methods were used:

The preliminary test. The initial coal sample is placed in a cylinder with a $250 \mathrm{ml}$ volume. In the second cylinder (which is empty), a flocculant solution (concentration $0,05 \%$ ) with a $0,5 \mathrm{~cm}^{3}$ volume is placed. After that the coal pulp is shuffled between the cylinders 4 times. After this, the time is determined, for which the sedimentation front will pass between 230 and $190 \mathrm{ml}$ marks on the cylinder. It is desirable that this time would be in the 10-20 seconds gap. If the time is above 20 seconds, the flocculant dosage should be increased. If the time is below 10 seconds, the dosage should be decreased. After the initial dosage determination, one experiment with this dosage for each of the flocculants, which are present in testing, is carried. For each experiment, the time for the solid particles to pass between 230-190 ml marks is recorded, the size and stability of obtained aggregates and the clarity of water discharge in points (1 - not transparent, 5 - completely transparent) are visually measured. Based on the results obtained, as well as the information on which parameter (flocculant dosage, thickened product density, water discharge clarity) is a priority for the specific facility, 3-4 flocculants are selected from the whole set. For the main test, the flocculant that is currently used at the preparation plant must also be selected among the flocculants that were choosen during the preliminary test .

The main test. The initial coal sample with the $500 \mathrm{ml}$ volume is placed in a measuring cylinder. The cylinder is placed under a laboratory mixer with an anchor type impeller. The middle of the stirrer blades should be at the mark of $250 \mathrm{ml}$. The mixer's rotation speed should be $500 \mathrm{rpm}$. A flocculant solution is added in the process using a syringe after at least 20 seconds after the mixer's start have passed. At the same time, the stopwatch is turned on and exactly after 12 seconds (the average time that is sufficient to distribute the flocculant within the pulp) after the adding of the flocculant, the mixer is stopped. After that the time should be measured, at which the deposition front can pass between 450 and $350 \mathrm{ml}$ marks on the cylinder. After the measurement is complete, the cylinder is left for 30 minutes. Then the volume of the thickened product and the water discharge clarity are measured. If during the test it was observed that the flocculant is not fully distributed 
among the pulp, the mixing time should be increased, and if the flocculant destructuion has been observed, the time should be reduced.

\section{Laboratory testing}

Laboratory testing was conducted on the basis of setting up several series of parallel experiments, involving the following stages: grain size analysis, pleminary test and the main test. The research was conducted during various periods of coal preparation plant "Anzherskaya" operation (year 2017) with various technological parameters of the flotation process. As the evaluation criteria we have chosen the sedimentation rate, the solids content in the overflow and the sediment density. The sedimentation rate directly affects the radial thickener performance. More than that, at high sedimentation rate values there is no withdrawing of solid particles in the annual trough of radial thickener. The purity of the overflow plays an important role due to the enclosed water-slurry factory scheme, and the sediment density shows the stability of formed aggregates and their resistance to dynamic loads. This influences both the thickening process efficiency and the polymer consumption rate.

To determine the group of flocculants that will be most effective on the tested coal feed of a radial thickener (flotation wastes), a preliminary evaluation of various flocculants was conducted (screening test). As a result, five flocculants were chosen: Magnaflock 155, Magnaflock 5250, Magnaflock 336, Magnaflock 355 and Magnaflock DP OMC 1047. Those flocculants have shown the shortest sedimentation time, most clear overflow and large stable floccula.

During the tests, the most valid performance belonged to the flocculants Magnaflock 355 and DP OMC. Further analysis has confirmed this. With the changes in the ash content value of the researched coal pulp from 14 to $71 \%$ and the solid content from 25 to $74 \mathrm{~g} / \mathrm{l}$, those flocculants have consistently allowed to achieve the optimal values of evaluation criteria. After comparing the two flocculants' efficiencies, preference was given to the flocculant Magnaflock 355, and therefore it was selected for the industrial testing at preparation plant "Anzherskaya".

\section{Industrial testing}

During the process, the following parameters were monitored:

- the anionic flocculant consumption rate;

- the clarity of radial thickener overflow (was determined by a turbidity meter that showed the content of suspended particles, $\mathrm{mg} / \mathrm{l}$ );

- the sedimentation time (was determined by a special glass tube that was lowered into the radial thickener with a marked interval of $30 \mathrm{~cm}, \mathrm{sec}$ );

- the sediment's height (was determined by a special glass tube that was lowered into the radial thickener).

The level of flotation foam on the surface of the radial thickener was determined visually, in points from 1 to 5 ( 1 - minimal, 5 -maximal). This value helps to comprehend not only the flocculant efficiency during the clay particles thickening, but also during the coal particles thickening.

During the tests the effective working range of flocculant was estimated, because under the constant fluctuations in in the quantitative and qualitative values of processed coal it is the matter of most importance to be able to clearly see the stability of the applied flocculant. 
The application of the cationic flocculant Magnaflok 380 was not corrected, its consumption rate remained unchanged at $30 \mathrm{~g} / \mathrm{t}$. The results of the thickener performance when using the anionic flocculant Magnaflok 5250 are presented in the Table 1.

Table 1. The efficiency of the thickening process when using anionic flocculant Magnaflock 5250.

\begin{tabular}{|c|c|c|c|c|c|c|c|c|c|}
\hline Date & \multicolumn{4}{|c|}{$\mathbf{0 6 . 0 1 . 1 8}$} & \multicolumn{4}{|c|}{$\mathbf{0 7 . 0 1 . 1 8}$} \\
\hline Time & $16-00$ & $\begin{array}{c}18- \\
00\end{array}$ & $\begin{array}{c}20- \\
00\end{array}$ & $\begin{array}{c}22- \\
00\end{array}$ & $24-00$ & $2-00$ & $4-00$ & $6-00$ & $8-00$ \\
\hline $\begin{array}{c}\text { Flocculant } \\
\text { consumption } \\
\text { rate, g/t }\end{array}$ & 40 & 40 & 40 & 40 & 40 & $\begin{array}{c}\text { Thickener } \\
\text { feed is } \\
\text { stopped }\end{array}$ & 40 & 40 & 40 \\
\hline $\begin{array}{c}\text { Overflow } \\
\text { clarity, mg/1 }\end{array}$ & 900 & 850 & 870 & 920 & 1000 & - & 910 & 1100 & 930 \\
\hline $\begin{array}{c}\text { Sedimentation } \\
\text { time, sec }\end{array}$ & 50 & 57 & 52 & 48 & 46 & - & 50 & 40 & 54 \\
\hline $\begin{array}{c}\text { Sediment's } \\
\text { height, mm }\end{array}$ & 80 & 82 & 81 & 79 & 77 & - & 79 & 76 & 80 \\
\hline $\begin{array}{c}\text { Foam level, } \\
\text { points }\end{array}$ & 4 & 3 & 3 & 4 & 4 & - & 4 & 4 & 4 \\
\hline
\end{tabular}

At 10-00 the flocculant Magnaflock 5250 was replaced by Magnaflock 355. The results are listed in the Table 2.

Table 2. The efficiency of the thickening process after replacing the flocculant Magnaflock 5250 by Magnaflock 355.

\begin{tabular}{|c|c|c|c|c|c|c|c|c|c|}
\hline Date & \multicolumn{8}{|c|}{07.01 .18} & 08.01 \\
\hline Time & $\begin{array}{l}10- \\
00\end{array}$ & $12-00$ & $\begin{array}{c}14- \\
00\end{array}$ & $\begin{array}{c}16- \\
00\end{array}$ & $\begin{array}{c}18- \\
00\end{array}$ & $\begin{array}{c}20- \\
00\end{array}$ & $\begin{array}{c}22- \\
00\end{array}$ & $\begin{array}{c}24- \\
00\end{array}$ & $2-00$ \\
\hline $\begin{array}{l}\text { Flocculant } \\
\text { consumption } \\
\text { rate, } g / t\end{array}$ & 40 & $\begin{array}{l}\text { Thickener } \\
\text { feed is } \\
\text { stopped }\end{array}$ & 40 & 40 & 40 & 35 & 35 & 35 & $\begin{array}{l}\text { Thickener } \\
\text { feed is } \\
\text { stopped }\end{array}$ \\
\hline $\begin{array}{c}\text { Overflow } \\
\text { clarity, mg/l }\end{array}$ & 700 & - & 600 & 650 & 640 & 720 & 740 & 730 & - \\
\hline $\begin{array}{l}\text { Sedimentation } \\
\text { time, sec }\end{array}$ & 35 & - & 32 & 34 & 32 & 35 & 37 & 35 & - \\
\hline $\begin{array}{l}\text { Sediment's } \\
\text { height, } \mathrm{mm}\end{array}$ & 70 & - & 72 & 74 & 71 & 75 & 77 & 75 & - \\
\hline $\begin{array}{c}\text { Foam level, } \\
\text { points }\end{array}$ & 3 & - & 3 & 3 & 2 & 2 & 2 & 2 & - \\
\hline
\end{tabular}

During the testing Magnaflock 355 continued to be put in the process. The results are listed in the Table 3.

Table 3. The efficiency of the thickening process when using anionic flocculant Magnaflock 355.

\begin{tabular}{|c|c|c|c|c|c|c|c|c|c|}
\hline Date & \multicolumn{9}{|c|}{$\mathbf{0 8 . 0 1 . 2 0 1 8}$} \\
\hline Time & $4-00$ & $6-00$ & $8-00$ & $10-00$ & $\begin{array}{c}12- \\
00\end{array}$ & $14-00$ & $\begin{array}{c}16- \\
00\end{array}$ & $\begin{array}{c}18- \\
00\end{array}$ & $20-00$ \\
\hline $\begin{array}{c}\text { Flocculant } \\
\text { consumption } \\
\text { rate, g/t }\end{array}$ & 35 & 35 & 35 & $\begin{array}{c}\text { Thickener } \\
\text { feed is } \\
\text { stopped }\end{array}$ & 35 & 35 & 35 & 35 & $\begin{array}{c}\text { Thickener } \\
\text { feed is } \\
\text { stopped }\end{array}$ \\
\hline $\begin{array}{c}\text { Overflow } \\
\text { clarity, mg/l }\end{array}$ & 680 & 720 & 700 & - & 700 & 710 & 720 & 700 & - \\
\hline
\end{tabular}




\begin{tabular}{|c|c|c|c|c|c|c|c|c|c|}
\hline $\begin{array}{c}\text { Sedimentation } \\
\text { time, sec }\end{array}$ & 35 & 35 & 38 & - & 36 & 35 & 36 & 34 & - \\
\hline $\begin{array}{c}\text { Sediment's } \\
\text { height, mm }\end{array}$ & 75 & 74 & 75 & - & 74 & 76 & 75 & 75 & - \\
\hline $\begin{array}{c}\text { Foam level, } \\
\text { points }\end{array}$ & 2 & 2 & 2 & - & 2 & 2 & 2 & 2 & - \\
\hline
\end{tabular}

From 22-30 Magnaflock 5250 is once again used in the thickening process. The results are listed in the table 4.

Table 4. The efficiency of the thickening process when using anionic flocculant Magnaflock 5250.

\begin{tabular}{|c|c|c|c|c|c|c|c|c|}
\hline Date & \multicolumn{9}{|c|}{08.01 .2018} \\
\hline Time & $1-00$ & $3-00$ & $5-00$ & $7-00$ & $9-00$ & $11-00$ & $13-00$ & $15-00$ \\
\hline $\begin{array}{c}\text { Flocculant } \\
\text { consumption } \\
\text { rate, g/t }\end{array}$ & 35 & 35 & 35 & 40 & 40 & $\begin{array}{c}\text { Thickener } \\
\text { feed is } \\
\text { stopped }\end{array}$ & 40 & 40 \\
\hline $\begin{array}{c}\text { Overflow } \\
\text { clarity, mg/l }\end{array}$ & 1500 & 1600 & 1600 & 950 & 920 & - & 850 & 900 \\
\hline $\begin{array}{c}\text { Sedimentation } \\
\text { time, sec }\end{array}$ & 60 & 63 & 62 & 53 & 55 & - & 55 & 54 \\
\hline $\begin{array}{c}\text { Sediment's } \\
\text { height, mm }\end{array}$ & 82 & 81 & 85 & 80 & 79 & - & 79 & 77 \\
\hline $\begin{array}{c}\text { Foam level, } \\
\text { points }\end{array}$ & 2 & 2 & 3 & 3 & 3 & - & 3 & 3 \\
\hline
\end{tabular}

\section{Conclusions}

As shown by industrial testing, in comparison with Magnaflock 5250, that was used at the plant originally, the best results were achieved with the usage of Magnaflok 355, which was selected during the laboratory testing. The reduction in the content of suspended solid particles in the overflow of the radial thickener takes place. During the usage of Magnaflock 5250 the clarity of radial thickener overflow was $900-1000 \mathrm{mg} / \mathrm{l}$, but, when replaced by Magnaflock 355, it became 600-700 g/l. During the tests the reduction in the level of flotation foam was noted.

Improvements in the performance of the thickening process can be explained by the correlation of the properties of the flocculant and the working pulp. Magnaflock 355 has lower molecular weight than Magnaflock 5250, which allows faster distribution inside the pulp and faster aggregate forming. Under the conditions of preparation plant "Anzherskaya" this gives a significant advantage to that flocculant due to the small size of the installed at the plant radial thickener (diameter $12 \mathrm{~m}$ ). The smaller anion charge of Magnaflock 355 allows it to selectively work with fine coal particles, which represent a significant percentage of the total mass of the condensed pulp. The average molecular weight of Magnaflock 355 makes it possible to obtain stable results under the significant fluctuations in the ash content values of the processed coal.

Thus, the selection of a flocculant by analyzing the properties of the flocculated pulp and the subsequent correlation of these properties with the properties of the flocculant itself has proved to be quite effective. Further testing on the coal pulps with a wider range of characteristics may allow even more effective results in selecting a flocculant to be used at a coal preparation plant without its direct testing on the particular pulp. 


\section{References}

1. K. Alekseev, XVII International Coal preparation congress (Saint-Petersburg Mining University, Saint-Petersburg, 2013)

2. S. M. Glover, Y. D. Yan, G. J. Jameson, S. Biggs, VI World Congress of Chemical Engineering (UGGH, Berlin, 2001)

3. J. Gregory, Solid/Liquid Dispersions (Academic Press Inc., London, 1987)

4. D. F. Lawler, Water Sci. Technol. 4, 15 (1997)

5. V. Urbain, J.C. Block, J. Manem, Water Res. 5, 82 (1993)

6. M. Kaiser, H. Latsch Proceedings of the 12th International Coal Preparation Congress (Saint-Petersburg Mining University, Saint-Petersburg, 1994)

7. V.S. Frolov, L.N. Merkusheva, D.V. Frolov, A.V. Sidorov, XVIII International Coal Preparation Congress, Saint-Petersburg Mining University (Saint-Petersburg Mining University, Saint-Petersburg, 2016)

8. V.S. Frolov, XVII International Coal Preparation Congress (Saint-Petersburg Mining University, Saint-Petersburg, 2013)

9. J. Gregory, The Effect of Polymers on Dispersion Properties (Academic Press Inc., London, 1982)

10. S. Biggs, M. Habgood, G.J. Jameson, Yao-de Yan, Proceedings of the 26th Australian Chemical Engineering Conference (HGTA, Adelaida,1998)

11. M. Y. Lin, H. M. Lindsay, D. A. Weitz, R. C. Ball, R. Klein, R. C. Ball, P. Meakin, J. Phys: Condens. Matter, 2, 3093 (1990)

12. M. Elimelich, J. Gregory, X. Jia and R. William, Particle deposition and aggregation: Measurement, modeling and simulation (Butterworth-Heinemann, Oxford, 1995)

13. L. A. Spielman, The Scientific Basis of Flocculation (Sijthoff, Noordhoff, 1978)

14. C. Selomulya The Effect of Shear on Flocculation and Floe Size\&Structure: PhD Thesis (The University of New South Wales, Australia, 2001)

15. P. T. Spicer, Shear-Induced Aggregation-Fragmentation: Mixing and Aggregate Morphology Effects: PhD Thesis (University of Cincinnati, Blue Ash, 1997) 